\title{
Analisis Faktor - Faktor yang Mempengaruhi Terjadinya Fraud
}

\author{
Asep Suryana ${ }^{1}$, Dadang Sadeli ${ }^{2}$ \\ ${ }^{1}$ Universitas Pancasila, Jl. Srengseng Sawah, Jagakarsa, Jakarta Selatan 12640 \\ ${ }^{2}$ Universitas Pendidikan Indonesia, Jl. Dr. Setiabudhi No. 229 Bandung 40381 Jawa Barat
}

\section{N F O A R T I K E L}

\section{JEL Classification:}

$\mathrm{H} 22$

$\mathrm{I} 22$

\section{Keywords:}

work environtment, personal attitude, administration system, fraud

\section{A $B$ S T R A C T}

Fraud can happen in the work environment in field of education. The purpose of this study was to demonstrate and explain empirically that there is the influence of the working environment, personal attitude and administration system against fraud. The study was conducted by survey method. Samples are 84 administrative employees and teachers in SMA and SMK Sukabumi. Testing is done by multiple linear regression analysis. Instruments adopted from previous research. Validity and reliability tests conducted before hypothesis test. The research proves that the work environment against fraud. Personal influence attitude and system administration against fraud is not proven significantly.

\section{A B S T R A K}

Kecurangan dapat terjadi di lingkungan kerja di bidang pendidikan. Tujuan penelitian ini adalah untuk membuktikan dan menjelaskan secara empiris bahwa ada pengaruh lingkungan kerja, personal attitude dan sistem administrasi terhadap fraud. Penelitian dilakukan dengan metode survey. Sampel adalah 84 pegawai tata usaha dan guru di SMAN dan SMKN Sukabumi. Pengujian dilakukan dengan uji regresi liner berganda. Instrumen diadopsi dari peneliti sebelumnya. Uji validitas dan reliabilitas dilakukan sebelum dilakukan uji hipotesis. Hasil penelitian membuktikan bahwa lingkungan kerja terhadap fraud. Pengaruh personal attitude dan sistem administrasi terhadap fraud tidak terbukti secara signifikan.

\section{Pendahuluan}

Membahas korupsi di Indonesia sama dengan membahas jalan yang tidak berujung. Dimulai dari mana dan berujung di mana. Dari rezim Orde Lama ke Orde Baru sampai dengan Orde Reformasi sekarang ini, perilaku korup dari "oknum-oknum" pemerintahan bukannya hilang ataupun berkurang tetapi malah kian menjadi dan merajalela.
Berbagai upaya telah dilakukan dalam memberantas tindak korupsi. Presiden telah membentuk KPK, lembaga independen yang secara khusus menangani kasus korupsi di negeri ini. Meskipun KPK telah dibentuk dalam upaya pencegahan dan penindakan tindak korupsi, korupsi di negeri ini tetap saja ada di berbagai tingkatan dan kuantitasnya tetap saja belum banyak berkurang baik dalam skala kecil maupun skala besar, mulai dari rakyat biasa hingga oknum 
pejabat di pemerintahan. Aspek yang paling menyedihkan dari kasus korupsi ini adalah, sebagian besar uang yang dicuri dialokasikan untuk warga miskin. Ini mencakup anggaran untuk dana bantuan operasional sekolah (BOS) dan dana bantuan sosial yang ditujukan untuk membangun gedung sekolah di wilayah-wilayah miskin dan terpencil di Indonesia. Salah satunya dugaan korupsi yang terjadi di Sukabumi yaitu mantan Kepala Sekolah SMAN 5 Kota Sukabumi ini menyelewengkan dana bantuan operasional sekolah (BOS) dan bantuan operasional manajemen (BOM) tahun anggaran 2010-2011.

Dana BOS-BOM ini berasal dari anggaran Pendapatan dan Belanja Negara (APBN), anggaran Pendapatan dan Belanja Daerah (APBD) Provinsi Jawa Barat dan APBD Kota Sukabumi. Dugaan penyelewengan dana ini totalnya mencapai Rp 500 Juta. Pada pelaksanaan penerimaan dana bantuan dari pemerintah yang diterima sekolah. Dalam inilahkoran.com yang di kutip pada tanggal 4 juli 2012 mengatakan bahwa kepala sekolah memerintahkan bendahara sekolah untuk melakukan penarikan atas danadana bantuan dari pemerintah secara bertahap dan diserahkan kepada kepala sekolah. Inilah kejadian yang terjadi bagaimana lingkungan kerja dapat mengakibatkan terjadinya fraud. Sedangkan personal attitude yang menjadi masalah adalah bagaimana seorang kepala sekolah menyuruh bawahannya untuk membuatkan laporan fiktif kepada bendaharanya di saat mendapatkan bantuan dari provinsi dan tidak ada realisasinya. Di kutip dari inilahkoran.com (2012).

Sistem administrasi yang telah mengakibatkan kerugian negara yaitu bantuan yang seharusnya diberikan kepada anak tidak mampu melalui program BKMM menurut jaksa penuntut umum tidak ada realisasinya dan kepala seklah memerintahkan kepada wakil kepala sekolah bidang kesiswaan untuk membuat laporan fiktif pula. Dikutip dari inilahkoran. com (2012). Berdasarkan kasus tersebut dapat di simpulkan bahwa bagaimana lingkungan kerja, personal attitude dan sistem administrasi yang telah ada dapat memungkinkan kecurangan terjadi di dalam dunia pendidikan dan bagaimana kecurangan ini juga dapat merugikan banyak pihak yang memang membutuhkan. Berdasaran fenomena yang terjadi di atas maka peneliti membuktikan faktor-faktor yang mempengaruhi terjadinya fraud pada di SMAN dan SMKN SeKota Sukabumi.

\section{Telaah Teori dan Pengembangan Hipotesis}

Teori yang menjelaskan hubungan prinsipal dan agen ini salah satunya berakar pada teori ekonomi, teori keputusan, sosiologi, dan teori organisasi. Teori prinsipal-agen menganalisis susunan kontraktual di antara dua atau lebih individu, kelompok, atau organisasi. Salah satu pihak (principal) membuat suatu kontrak, baik secara implisit maupun eksplisit, dengan pihak lain (agent) dengan harapan bahwa agen akan bertindak/melakukan pekerjaan seperti yang dinginkan oleh prinsipal (dalam hal ini terjadi pendelegasian wewenang). Hubungan prinsipalagen terjadi apabila tindakan yang dilakukan seseorang memiliki dampak pada orang lain atau ketika seseorang sangat tergantung pada tindakan orang lain. Hubungan atau ketergantungan ini diwujudkan dalam kesepakatan-kesepakatan dalam struktur institusional pada berbagai tingkatan, seperti norma perilaku dan konsep kontrak. Menurut Lane (2000) teori keagenan dapat diterapkan dalam organisasi publik. Ia menyatakan bahwa negara demokrasi modern didasarkan pada serangkaian hubungan prinsipalagen (Lane, 2000: 12-13).

\section{Fraud dan Jenis-jenis Fraud}

Definisi fraud menurut Black Law Dictionary (dikutip dalam Ramdany 2012:20) adalah :

A knowing misrepresentation of the truth or concealment of a material fact to induce another to act to his or her detriment; is usual a tort, but in some cases (eps. When the conduct is willful) $i$ may be a crime, 2. A misrepresentation made recklessly without belief in its truth to induce another person to act, 3. Atort arising from knowing misrepresentation, concealment of material 
fact, or recless misrepresentation made to induce another t act to his or her detriment.

Kesengajaan atas salah pernyataan terhadap suatu kebenaran atau keadaan yang disembunyikan dari sebuah fakta material yang dapat memHubungani orang lain untuk melakukan perbuatan atau tinfakan yang merugikan, biasanya merupakan kesalahan namun dalam beberapa kasus (khususnya dilakukan secara disengaja) memungkinkanmerupakan suatu kejahatan; 2. Penyajian yang salah/keliru (dalah pernyataan) yang secara ceroboh tanpa perhitungan dan tanpa dapat dipercaya kebenarannya berakibat dapat memhubungani atau menyebabkan orang lain bertindak atau berbuat; 3. Suatu kerugian yang timbul sebagai akibat diketahui keterangan atau penyajian yang salah (salah pernyataan), penyembunyian fakta material, atau penyajian yang ceroboh tanpa perhitungan yang memHubungani orang lain untuk beruat atau bertindak yang merugikannya.

Al-Qur'an dalam QS Al-Ahzab:72 Sesungguhnya Kami telah mengemukakan amanah kepada langit, bumi dan gunung-gunung, maka semuanya enggan untuk memikul amanah itu dan mereka khawatir akan mengkhianatinya, dan dipikullah amanah itu oleh manusia. Sesungguhnya manusia itu amat dzalim dan amat bodoh. Maka dari itu kenapa manusia mau menanggung amanah dari tuhannya.

Menurut Association of Certified Fraud Examiners (ACFE), internal fraud (tindakan penyelewengan di dalam perusahaan atau institusi) dikelompokan menjadi 3 jenis, yaitu:

1. Fraud Terhadap Aset (Aset Misappropriation) singkatnya, penyalahgunaan aset perusahaan (institusi), entah itu dicuri atau digunakan untuk keperluan pribadi tnpa ijin dari perusahaan. Seperti kita ketahui, aset perusahaan bisa berbentuk kas (uang tunai) dan non-kas. Sehingga, aset misappropriation dikelompokkan menjadi dua macam:

a. Cash Misappropriation Penyelewengan terhadap aset yang berupa kas (Misalnya: penggelapankas, nilep cek dari pelanggan, menahan cek pembayaran untuk vendor) b. Non-cash Missapropriation Penyelewengan terhadap aset yang berupa nonkas (misalnya: menggunakan fasilitas perusahaan untuk kepentingan pribadi)

2. Fraud terhadap Laporan Keuangan (Fraudullent Statements) -ACFE membagi jenis fraud ini menjadi 2 macam, yaitu: a) financial; dan b) non financial. Segala tindakan yang membuat laporan keuangan menjadi tidak seperti yang seharusnya (tidak mewakili kenyataan), tergolong kelompok fraud terhadap laporan keuangan. Misalnya:

a. Memalsukan bukti transaksi

b. Mengakui suatu transaksi lebih besar atau lebih kecil dari yang seharusnya.

c. Menerapkan metode akuntansi tertentu secara tidak konsisten untuk menaikan atau menurnkan laba.

d. Menerapkan metode pengakuan aset sedemikian rupa sehingga aset menjadi nampak lebih besar dibandingkan yang seharusnya.

e. Menerapkan metode pengakuan liabilitas sedemikian rupa sehingga liabilitas menjadi nampak lebih kecil dibandingkan yang seharusnya.

3. Korupsi (Corruption) ACFE membagi jenis tindakan korupsi menjadi 2 kelompok, yaitu:

a. Konflik kepentingan (conflict of interest) ini merupakan benturan kepentingan cntoh sederhananya: seseorang atau kelompok orang di dalam perusahaan (biasanya manajemen level) memiliki hubungan istimewa dengan pihak luar (entah itu orang atau badah usaha). Dikatakan memiliki hubungan istimewa karena memiliki kepentingan tertentu (misalnya: punya saham, anggota keluarga, sahabat dekat, dan lain-lain). Ketika perusahaan bertransaksi dengan pihak luar ini, apabila seorang manajer/eksekutif mengambil keputusan tertentu untuk melindungi kepentingannya itu, sehingga mengakibatkan kerugian bagi perusahaan, maka ini termasuk tindakan fraud. Hal tersebut sering disebut sebagai kolusi dan nepotisme. 
b. Menyuap atau menerima suap, imbal balik (briberies and excoriation) suap, menyaup dan menerima suap, merupakan tndakan fraud. Tindakan lain yang masuk dalam kelmpok fraud ini adalah: menerima komisi, membocorkan rahasia perusahaan (baik berupa data atau dokumen) apapun bentuknya, kolusi dalam tender tertentu

\section{Faktor- Faktor yang Mempengaruhi Fraud}

Menurut Oversights System Report on Corporate Fraud (2007), alasan utama yang menyebabkan terjadinya fraud adalah :

1. Adanya tekanan untuk memenuhi kebutuhan.

2. Untuk mendapatkan keuntungan.

3. Tidak menganggap apa yang dilakukannya adalah termasuk fraud.

Namun didalam pengkajian yang mendalam, dapat kita kelompokan empat faktor pendorong seseorang untuk melakukan kecurangan, sering disebut dengan teori GONE, yaitu:

1. Greed (keserakahan)

2. Opportunity (kesempatan)

3. Need (kebutuhan)

4. Exposure (kebutuhan)

Faktor Greed dan Need merupakan faktor individual yang berhubungan dengan individu pelaku kecurangan, sedangkan faktor Opportunity dan Exposure merupakan faktor generik / umum yang berhubungan dengna organisasi sebagai korban perbuatan kecurangan (Tuanakota, 2010). Seseorang dipercaya menjadi pelanggar ketika ia melihat dirinya sendiri sebagai orang yang mempunyai masalah keuangna yang tidak dapat diceritakannya kepada orang lain, sadar bahwa masalah ini diam-diam dapat diatasi dengan menyalahgunakan wewenangnya sebagai pemegang kepercayaan di bidang keuangan, dan tindak tanduk sehari-hari memungkinkannya menyesuaikan pandangan mengenai dirinya sebagai seorang yang bisa dipercaya dalam menggunakan dana atau kekayaan yang dipercayakan:, dalam perkembangan selanjutnya hipotesis ini dikenal sebagai fraud triangle (segitiga fraud).

\section{Pengaruh Lingkungan Kerja terhadap Fraud}

Lingkungan kerja dalam suatu organisasi termasuk salah satu hal yang penting untuk diperhatikan. Meskipun lingkungan kerja tidak melaksanakan prosese produksi dalam suatu perusahaan, namum lingkungan kerja mempunyai Hubungan langsung terhadap para karyawan yang melaksanakan proses produksi tersebut. Lingkungan kerja yang akan memberikan kesempatannya untuk dapat melaksanakan tugasnya dengan sebaiknya. Sebaliknya lingkungan kerja yang tidak memadai akan dapat memHubungani cara karyawan bekerja yang akhirnya dapat melakukan tindakan-tindakan yang dapat merugikan perusahaan.

Menurut Lewa dan Subowo (2005) lingkungan kerja didesain sedemikian rupa agar dapat terciptanya hubungan kerja yang mengikat pekerja dengan lingkungannya. Lingkungan kerja yang baik yaitu apabila karyawan dapat melaksanakan kegiatan secara optimal, sehat, aman dan nyaman. Lingkungan kerja yang kurang baik dapat menuntut tenaga kerja serta waktu yang lebih banyak dan tidak mendikung diperlohnya rancangan sistem kerja yang efisien. Nitisemito (2000:183) mendifinisikan lingkungan kerja sebagai berikut :

"lingkungan kerja adalah segala sesuatu yang ada disekitar para pekerja yang dapat menghubungkan dirinya dalam menjalakam tugas-tugas yang diembannya" Menurut Sedarmayanti (2009) definisi lingkungan kerja adalah sebagai berikut :"Lingkungan kerja adalah keseluruhan alat perkakas dan bahan yang dihadapi, lingkunga sekitarnya dimana seseorang bekerja, metode kerjanya, serta pengaturan kerjanya baik perseorangan maupun kelompok".

Menurut Schultz \& Schultz (2006) lingkungan kerja diartikan sebagai suatu kondisi yang berkaitan dengan ciri-ciri tempat bekerja terhadap perilaku dan sikap pegawai dimana hal tersebut berhubungan dengan terjadinya perubahan psikologis karena hal-hal yang dialami 
pekerjaannya atau dalam keadaan tertentu yang harus terus diperhatikan oleh organisasi yang mencakup kebosanan kerja, pekerjaan yang monoton serta kelelahan.

Berdasarkan eberapa pendapat yang telah dikemukakan oleh para ahli dapat disimpulkan bahwa lingkunga kerja meupakan segala sesuatu yang ada disekitarnya yang dapat memHubungani dirinya serta pekerjaannya disaat melakukan segala aktivitasnya didalam perusahaan. Pada lingkungan kerja yang sedemikian permisif dengan suap, menjadi tidak wajar jika seseorang menolak suap. Dalam lingkungan kerja yang sedemikian mengagungkan penampilan yang dibalut kemewahan, maka seseorang yang berpenampilan sederhana dianggap sebagai kolot dan konyol. Dalam lingkungan keluarga yang mengagungkan kekayaan materi sebagai ukuran kesejahteraan, maka seseorang yang tidak kaya materi akan dianggap tidak berhasil dalam menjalani kehidupannya. Dalam lingkungan keluarga yang tidak pernah puas dengan yang dicapai dan dimiliki, maka seseorang akan selalu terobsesi untuk memiliki segalanya. Lingkungan seperti ini kemudian dapat menekan atau mendorong psikologis seseorang untuk melakukan tindakan curang yang mungkin dapat dia lakukan.

Lingkungan kerja salah satu faktor yang dapat mempengaruhi terjadinya tindakan fraud. Karena dalam lingkungan kerja terdapat fasilitas kerja, gaji dan tunjangan, serta hubungan kerja antar personal.

Berkaitan dengan pengendalian internal, Committee of Sponsoring Organizations (COSO) mengharuskan perusahaan untuk memiliki kerangka pengendalian internal sebagai berikut:
a. lingkungan pengendalian yang baik
b. penilaian resiko
c. aktivitas pengendalian yang baik
d. arus komunikasi dan informasi yang baik
e. pengawasan

Dari kelima unsur yang disebutkan pada kerangka di atas, Albrecht, dan Zimbelman (2009:110) terfokus pada: Lingkungan pengendalian, merupakan lingkungan kerja yang diciptakan atau dibentuk oleh perusahaan bagi para karyawan.
Hasil survei yang dilakukan oleh KPMG dalam “KPMG, 1998 Fraud Survey”(New York: KPMG, 1998) dalam Mustofa (2004) menunjukan bahwa dari jawaban responden, lemahnya pengendalian intern merupakan penyebab tertinggi terjadinya kecurangan (fraud). (dikutip dalam skripsi lisa amelia 2013:3) Berdasarkan pendapat diatas maka peneliti diduga bahwa lingkungan kerja mempunyai pengaruh terhadap terjadinya fraud

\section{Pengaruh Personal Attitude terhadap Fraud}

Kepribadian seseorang juga mempunyai hubungan terjadinya suatu tindakan kecurangan. Orang yang jujur dimanapun di tempatkan akan berlaku jujur sebaliknya orang yang mempunyai karakter curang juga mempunyai kecenderungan curang dalam keseharianya. Umumnya kepribadian yang baik dilandasi dengan keimanan yang kokoh.

Pengertian perilaku individu menurut Gibson Cs. (1996) menyatakan perilaku individu adalah segala sesuatu yang dilakukan seseorang, seperti : berbicara, berjalan, berfikir atau tindakan dari suatu sikap. Sedangkan menurut Kurt Levin, perilaku (behavior) individu pada dasarnya merupakan fungsi dari interakasi antara person/ individu yang bersangkutan dengan lingkungan (enviroment).

Dari pengertian tersebut perilaku individu dapat diartikan sebagai suatu sikap atau tindakan serta segala sesuatu yang dilakukan manusia baik yang dilakukan dalam bekerja maupun diluar pekerjaan seperti berbicara, bertukar pendapat, berjalan dan sebagainya. Setiap individu mempunyai karakteristik yang berbeda, sehingga setiap manusia mempunyai keunikan-keunikan tersendiri. Oleh sebab itu antara individu yang satu dengan yang lain pasti mempunyai perbedaanperbedaan.

Ada beberapa alasan mengapa manusia berperilaku berbeda :

1. Manusia berbeda perilakunya karena kemampuannya tidak sama.

2. Manusia mempunyai kebutuhan yang berbeda.

3. Orang berfikir tentang masa denap dan 
membuat pililhan tentang bagaimana bertindak.

4. Seseorang memahami lingkungannya dalam hubungannya dengan bagaimana masa lalu dan kebutuhannya.

5. Seseorang mempunya reaksi-reaksi tidak senang.

Sikap seseorang juga merupakan faktor yang mendorong untuk melakukan fraud terutama sikap mereka yang gemar melakukan kecurangan (kebohongan). Fraud yang berdasarkan sikap seseorang ini umumnya dilatar belakangi oleh tekanan hidup dan kebutuhan, kemudian adanya kesempatan untuk melakukan fraud dan terakhir adanya pembenaran yang di dasari oleh rasional dalam melakukan tindakan fraud. Cressey (dikutip oleh Skousen et al., 2009) menyimpulkan bahwa kecurangan secara umum mempunyai tiga sifat umum. Faktor resiko kecurangan tersebut adalah pressure, opportunity, dan rationalization yang disebut juga sebagai "fraud triangle". Menurut teori Crassey, pressure, opportunity, dan rationalization selalu hadir pada situasi fraud. Fraud triangle secara umum terdiri dari tiga kondisi yang hadir ketika fraud muncul: Incentive/pressure, Opportunity, dan Attitudel rationalizations (Turner, et al., 2003). Konsep fraud triangle diperkenalkan dalam literatur professional pada SAS No.99, Consideration of Fraud in a Financial Statement audit (Skousen et al., 2009). Berdasarkan pendapat diatas maka peneliti menduga bahwa personal attitute/perilaku seseorang mempunyai pengaruh terhadap terjadinya fraud.

\section{Pengaruh Sistem Administrasi terhadap Fraud}

Sistem adalah sekumpulan sumber daya yang berhubungan untuk mencapai tujuan tertentu (menurut bodnar 2000,pl), Sedangkan administrasi adalah keseluruhan proses kerjasama antara dua orang atau lebih yang didasarkan atas rasionalitas tetentu dalam rangka pencapaian tujuan yang telah ditentukan sebelumnya dengan memanfaatkan sarana dan prasarana tertentu secara berdaya guna (kamus besar bahasa indonesia 2002). Kesimpulan tentang sistem administrasi adalah suatu kegiatan atau usaha untuk mengarahkan semua kegiatan dalam mencapai suatu tujuan dengan memanfaatkan sumber daya manusia serta sarana prasarana.

Hartono, et.al (2003) memberikan batasan mal-administrasi secara umum yaitu perilaku yang tidak wajar termasuk penundaan pemberian pelayanan, tidak sopan dan kurang peduli terhadap masalah yang menimpa seseorang disebabkan oleh perbuatan penyalahgunaan kekuasaan, termasuk penggunaan kekuasaan secara semena-mena atau kekuasaan yang digunakan untuk perbuatan yang tidak wajar, tidak adil, intimidatif atau diskriminatif, dan tidak patut didasarkan seluruhnya atau sebagian atas ketentuan undang-undang atau fakta, tidak masuk akal, atau berdasarkan tindakan unreasonable, unjust, oppressive, improper dan diskriminatif. Mal-administrasi dapat merupakan perbuatan, sikap maupun prosedur dan tidak terbatas pada hal-hal administrasi dalam pengertian sempit atau tata usaha. Hal-hal mal-administrasi tersebut menjadi salah satu penyebab bagi timbulnya pemerintahan yang tidak efisien, buruk dan tidak memadai. Dengan lain perkataan, tindakan atau perilaku mal-administrasi bukan sekedar merupakan penyimpangan dari prosedur atau tata cara pelaksanaan tugas pejabat atau aparat negara atau aparat penegak hukum, tetapi juga dapat merupakan perbuatan melawan hukum (onrechmatige overheidsdaad), détournement de pouvoir atau détournement de procedure.

Fraud juga di tunjang juga dengan sistem administrasi yang ada di lembaga tersebut sehingga memberikan peluang yang dapat dimanfaatkan oleh si pelaku fraud itu sendiri, sehingga memungkinkan seseorang melakukan tindakan kecurangan lebih besar dikarenakan sistem administrasi yang ada kurang menunjang dalam setiap pelaksanaan setiap kegiatan.

Masthuri (2005), mengatakan maladministrasi adalah suatu praktek yang menyimpang dari etika administrasi, atau suatu praktek administrasi yang menjauhkan dari pencapaian tujuan administrasi. Contoh praktek mal-administrasi yang termasuk dalam kategori titik kritis dalam SANKRI seperti yang 
dikemukakan Menpan dalam Irian, et al (2009) yaitu: inefisiensi, inefektifitas, tidak profesional, tidak netral, tidak disiplin, tidak patuh pada aturan, retrutmen Calon Pegawai Negeri Sipil (CPNS) tidak transparan, belum ada perubahan mindset, Korupsi, Kolusi, dan Nepotisme (KKN) yang marak di berbagai jenjang pekerjaan, sebagai abdi masyarakat belum terbangun, pemerintahan belum akuntabel, belum transparan, tidak partisipatif dan kredibel, lemahnya political will valid apabila pertanyaan dalam kuesioner tersebut mampu mengungkapkan sesuatu yang akan di ukur oleh kuesioner tersebut. Hasil pengujian menunjukkan bahwa item pengukur variable Lingkungan Kerja (X1), Personal Attitude (X2), dan Sistem Administrasi (X3) terhadap Fraud (Y) menunjukan hasil yang signifikan $(<0,05)$. Jadi dapat disimpulkan bahwa masing-masing indikator pertanyaan adalah valid.

Uji reliabilitas digunakan untuk mengetahui konsistensi alat ukur, apakah alat

Tabel 1. Tabel Hasil Uji Reliabilitas

\begin{tabular}{clccc}
\hline Variabel & Nama Variabel & Koefisien Reliabilitas & $\begin{array}{c}\text { Titik } \\
\text { Batas }\end{array}$ & Keterangan \\
\hline X1 & Lingkungan Kerja & 0,638 & 0,6 & Cukup Reliabel \\
X2 & Personal Attitude & 0,574 & 0,6 & Kurang Reliabel \\
X3 & Sistem Administrasi & 0,611 & 0,6 & Cukup Reliabel \\
Y & Fraud & 0,644 & 0,6 & Cukup Reliabel \\
\hline
\end{tabular}

dari pemerintah, belum ada kesamaan persepsi dan pemahaman visi, misi dan tujuan serta ketidakjelasan rencana tindak dalam lembaga negara, kurangnya pemanfaatan teknologi informasi (TI) dalam pemberantasan KKN, masih banyak ditemukan peraturan perundang-undangan yang rancu antara sektoral dan pemerintah daerah, pelayanan publik belum berkualitas dan pelayanan publik prima belum terbangun secara luas. Berdasarkan pendapat diatas maka peneliti menyimpulkan bahwa sistem administrasi mempunyai pengaruh terhadap terjadinya fraud.

\section{Metode}

Responden yang digunakan dalam penelitian ini adalah pegawai tata usaha dan guru yang di ambil sampel secara acak. Dengan total responden sebanyak 90 kuesioner dan yang mengembalikan sebanyak 84 kuesioner yang di sebarkan ke seluruh sekolah SMAN dan SMKN yang ada di Kota Sukabumi. Uji validitas adalah ketepatan atau kecermatan suatu instrumen dalam mengukur apa yang ingin diukur dan dalam hal ini adalah untuk mengukur valid atau tidaknya suatu kuesioner. Suatu kuesioner dapat dikatakan pengukur yang digunakan dapat diandalkan dan tetap konsisten jika pengukuran tersebut diulang. Suatu kuesioner dikatakan reliabel atau handal jika jawaban seseorang terhadap pertanyaan adalah konsisten atau stabil dari waktu kewaktu. Artinya responden akan memberikan jawaban hampir sama terhadap kuesioner yang diberikan. Hasil pengujian menunjukkan bahwa item0iten yang digunakan sebagai pengukur cukup reliable. Hasil uji reliabilitas sebagaimana terangkum pada Tabel 1.

Pengujian berikutnya adalah uji asumsi klasik sebagai syarat untuk untuk pengujian regresi berganda. Uji regresi berganda disyaratkan memenuhi uji asumsi klasik yang mencakup normalitas dan multikolinearitas. Hasil uji normalitas data digunakan untuk mengetahui apakah model regresi, variabel penganggu atau residual memiliki distribusi normal atau untuk mengetahui apakah data yang diambil dari populasi berdistribusi normal. Model regresi yang baik adalah data berdistribusi normal atau mendekati normal. Hasil Uji KolmogorovSmirnov adalah sebesar 0,996 dan signifikansi 0,275 lebih besar dari alpha (0.05). Dengan demikian dapat dinyatakan bahwa distribusi 
data dari masing-masing variabel berdistribusi normal. Uji heteroskedastisitas tidak dilakukan dalam penelitian ini dengan asumsi, data yang terdistribusi normal dapat dipastikan merupakan data yang homogeny.

Uji multikolinearitas digunakan untuk mengetahui ada atau tidaknya penyimpangan asumsi klasik multikolinearitas yaitu adanya hubungan linear antar variabel independen dalam model regresi. Prasyarat yang harus terpenuhi dalam model regresi adalah tidak adanya multikolinearitas. Hasil tabel diatas memperlihatkan perhitungan nilai toleransi tidak menunjukan nilai kurang dai 0,10 yang berarti tidak ada korelasi antar variabel independen yang nilainya lebih dari 95\%. Dan juga hasil perhitungan Variance Inflation Factor (VIF) (kurang dari) $<10$, maka dapat disimpulkan bahwa tidak ada multikolinieritas antar variabel bebas model regresi ini.

Pengujian hipotesis menggunakan uji regresi berganda. Uji F dan koefisien determinasi digunakan untuk menguji model penelitian (goodness of fit model), Uji $\mathrm{t}$ digunakan menguji pengaruh masing-masing variable independen terhadap dependen variabelnya. Hipoteis dikatakan terbukti jika hasil pengujian menunjukkan nilai signifikasi $<0.05$ (pada $\alpha=5 \%$ ).

\section{Hasil Penelitian dan Pembahasan}

Pengujian hipotesis dilakukan dengan Uji regresi linier berganda. Rangkuman hasil penelitian sebagaimana tampak pada Tabel 2.
Berdasarkan hasi ${ }^{11}$ pengujian maka persamaan regresi dapat ditulis sebagai berikut:

$$
\mathrm{Y}=1,111+0,501 \mathrm{X} 1+-0,023 \mathrm{X} 2+0,211 \mathrm{X} 3+\mathrm{e}
$$

Nilai konstanta sebesar 1,111 berarti bila variabel Fraud (Y) tidak di pengaruhi oleh ketiga variabel bebas (Lingkungan Kerja, Personal Attitude, Sisitem Administrasi) konstanta atau bernilai ol maka besarnya nilai Fraud sebesar 1,111. Koefisien regresi X1 bernilai posistif menunjukan adanya hubungan searah dengan Fraud artinya bila X1 (Lingkunga Kerja) meningkat sebesar satu satuan maka akan menyebabkan meningkatnya potensi Fraud (Y) sebesar 0,501. Koefisien regresi $\mathrm{X} 2$ bernilai negatif menunjukan tidak adanya hubungan searah dengan Fraud artinya bila X2 (Personal Attitude) meningkat sebesar satu satuan maka akan menyebabkan meningkatnya potensi Fraud (Y) sebesar 0,023.Koefisien regresi X3 bernilai posistif menunjukan adanya hubungan searah dengan Fraud artinya bila X3 (Sistem Administrasi) meningkat sebesar satu satuan maka akan menyebabkan meningkatnya potensi Fraud (Y) sebesar 0,211.

Koefisien Determinasi $\left(\mathrm{R}^{2}\right)$ ini menunjukkan seberapa besar prosentase variasi variabel independen yang digunakan dalam model mampu menjelaskan variasi variabel dependen. $\mathrm{R}^{2}$ sama dengan 0 , maka tidak ada sedikitpun prosentase sumbangan pengaruh yang diberikan variabel independen terhadap variabel dependen,

Tabel. 2 Hasil Pengujian

\begin{tabular}{lrrrr}
\hline \multicolumn{1}{c}{ Keterangan } & B & Std. Error & t-hitung & Sig. \\
\hline Lingkungan Kerja & .501 & .102 & 4.923 & .000 \\
Personal Atitude & -.023 & .286 & -.080 & .936 \\
Sistem Administrasi & .211 & .297 & .711 & .479 \\
Constant & 1.111 & .271 & 4100 & .000 \\
R-Square & 0.569 & & & \\
Adjusted R-Square & 0.552 & & & \\
F-hitung & 35.149 & & \\
Sig.F & 0.000 & - & \\
\hline
\end{tabular}


atau variasi variabel independen yang digunakan dalam model tidak menjelaskan sedikitpun variasi variabel dependen. Sebaliknya $\mathrm{R}^{2}$ sama dengan 1 , maka prosentase sumbangan pengaruh yang diberikan variabel independen terhadap variabel dependen adalah sempurna, atau variasi variabel independen yang digunakan dalam model menjelaskan $100 \%$ variasi variabel dependen.

Berdasarkan hasil pengolahan SPSS 20 diatas, diperoleh nilai $\mathrm{R}$ square sebesar 0,569, artinya adanya hubungan yang cukup kuat antara variabel bebas Lingkungan Kerja, Personal Attitude dan Sistem Administrasi terhadap variabel terikat Fraud yaitu sebesar 56,9\%. Sedangkan sisinya dari perhitungan $100 \%-56,9 \%$ $=43,1 \%$ dipengaruhi oleh faktor lain seperti: internal kontrol, pemahaman terhadap agama, nepotisme dan lain-lain. Hasil Uji Fmenunjukkan nilai 35,149 > Ftabel 1,80 dengan $\mathrm{p}$ value sebesar 0,000 (lebih kecil < dari a 5\% maka H0 di tolak, sehingga dapat disimpulkan bahwa secara simultan ada pengaruh yang cukup signifikan antara Lingkungan Kerja, Personal Attitude dan Sisitem Administrasi secara bersama-sama/ simultan terhadap Fraud.

Berdasarkan hasil uji t, variabel Lingkungan Kerja (X1) di peroleh t hitung sebesar 4,923 > t tabel 1.663 dan nilai p-value (sig) sebesar $0,000<\alpha 5 \%$ maka H01 di tolak dan Ha1 di terima. Artinya Lingkungan Kerja (X1) secara parsial mempunyai pengaruh yang signifikan terhadap Fraud(Y). Variabel Personal Attitude (X2) di peroleh t hitung sebesar -0,080 $>\mathrm{t}$ tabel 1.663 dan nilai $\mathrm{p}$-value (sig) sebesar $0,936<\alpha 5 \%$ maka Ho2 di terima dan Ha2 di tolak. Artinya Personal Attitude (X2) secara parsial tidak mempunyai pengaruh yang kurang signifikan terhadap Fraud(Y). Variabel Sisitem Administrasi (X3) di peroleh t hitung sebesar $0,711>\mathrm{t}$ tabel 1.663 dan nilai $\mathrm{p}$-value (sig) sebesar $0,479<\alpha 5 \%$ maka H01 di di tolak dan Ha1 di terima. Artinya Sistem Administrasi (X3) secara parsial mempunyai pengaruh yang kurang signifikan terhadap $\operatorname{Fraud}(\mathrm{Y})$.

Hasil penelitian ini menunjukan bahwa menolak H0 dan menerima H1 bahwa Lingkungan Kerja, Personal Attitude dan Sistem
Administrasi secara simultan berpengaruh cukup signifikan terhadap fraud. Hal ini berdasarkan $\mathrm{R}$ square sebesar $56,9 \%$ yang menunjukan bahwa Lingkungan Kerja, Personal Attitude dan Sistem Administrasi mampu menjelaskan variasi Fraud dengan tingkat yang cukup baik, sedangkan sisianya di pengaruhi oleh variabel lain di luar model. Dari hasil uji F telah di jelaskan bahwa Lingkunga Kerja, Personal Attitude dan Sistem Administrasi secara simultan berpengaruh cukup signifikan terhadap Fraud. Dari ketiga variabel bebas tersebut ternyata variabel Lingkungan Kerja $(0,501)$ memiliki pengaruh yang paling besar terhadap Fraud, kemudian variabel kedua adalah Personal Attitude (-0,023) tidak memiliki pengaruh yang signifikan. dan Sistem Administrasi $(0,211)$ mempunyai pengaruh yang cukup signifikan terhadap Fraud.

Hasiluji secaraparsial(ujit)menunjukkan bahwa lingkungan kerja mempunyai pengaruh yang cukup signifikan terhadap fraud. Dalam uji tersebut menunjukan tingkat lingkungan kerja pada sekolah yang cukup baik dengan di tunjukan oleh nilai thitung lebih besar dari ttabel yaitu sebesar 4,923 $>1.663$. Lingkungan kerja cukup ampuh dalam mencegah terjadinya kecurangan dalam lingkungan sekolah dan dapat menjaga setiap asset yang dimiliki oleh sekolah. Penelitian terdahulu yang dilakukan Tri Ramaraya Koroy (2008) menyimpulkan lingkungan kerja audityang terbatas dapat mengurangi kualitas audit dalam melakukan pendeteksian kecurangan. Sedangkan dalam penelitian ini penulis menyimpulkan bahwa lingkungan kerja sangat mempengaruhi terhadap fraud. Dikarenakan banyak hal salah satunya dari skor yang didapat dari data kuesioner yaitu pada poin ke tiga dan empat yang menyatakan yaitu tetntang saling menutupi kekurangan teman kerja adalah hal yang sangat biasa dan saling bekerjasama untuk mendapatkan sesuatu yang dibutuhkan adalah hal yang wajar dua poin itu yang menyebabkan terjadinya fraud yang terjadi didalam lingkungan sekolah.

Hasil uji secara parsial (uji t) menunjukkan bahwa personal attitude mempunyai pengaruh yang cukup signifikan terhadap fraud. Dalam uji tersebut menunjukan tingkat personal attitude 
para pegawai pada sekolah dengan di tunjukan oleh nilai thitung lebih kecil dari ttabel yaitu sebesar $-0,080>1.663$. Berdasakan data tersebut dapat disimpulkan bahwa sikap dan perilaku seseorang tidak mempunyai pengaruh untuk tidak melakukan fraud.

Penelitian yang dilakukan oleh Ramdany (2012) menyimpulkan bahwa tidak terdapat pengaruh yang signifikan antara personal attitude terhadap fraud secara parsial. Sikap seseorang merupakan hal yang sangat pribadi dan dipengaruhi oleh bermacam-macam faktor (keluarga, lingkungan masyarakat, lingkungan perusahaan dan sebagainya.

Hasil uji secara parsial (ujit) menunjukkan bahwa Sistem Administrasi mempunyai pengaruh yang cukup signifikan terhadap fraud. Dalam uji tersebut menunjukan bahwa Sistem Administrasi yang di gunakan oleh sekolah dengan di tunjukan oleh nilai thitung lebih kecil dari ttabel yaitu sebesar $0,711>1.663$. berdasarkan data tersebut dapat disimpulkan bahwa Sisitem Administrasi yang di bangun oleh sekolah mempunyai pengaruh yang kurang signifikan terhadap perilaku fraud. Penelitian yang dilakukan oleh Ayi Karyana (2011) Fraud merupakan mal-administrasi dan penyakit administrasi yang memicu rusaknya tatanan dan tujuan dari Sistem Administrasi Negara Kesatuan Republik Indonesia (SANKRI). Dan perlunya penguatan dan redefinisi SANKRI yang pada hakikatnya diarahkan untu menghindari terjadinya fraud, antara lain untuk menghindari terjadinya korupsi, penyelewengan, rekayasa, kecurangan dan pemborosan.

\section{Kesimpulan, Keterbatasan, dan Implikasi Hasil Penelitian}

Berdasarkan hasil penelitian yang telah dilakukan penulis menyimpulkan sebagai berikut:

1. Terdapat pengaruh yang signifikan antara lingkungan kerja, personal attitude dan sisitem admnistrasi terhadap fraud secara simultan. Faktor yang paling besar dalam mempengaruhi terjadninya fraud adalah lingkungan kerja dan sistem administrasi.
Lingkungan kerja yang kondusip dan saling memperhatikan antara satu dengan yang lainnya akan mengurangi tindakan fraud. Personal attitude adalah sikap pribadi seseorang yang dibawa sejak lahir dan pada dasarnya perilaku seseorang itu adalah baik tetapi banyak faktor dari luar yang dapat merubah individu tersebut. artinya sikap yang baik merupakan hasil bimbingan dari lingkungan yang baik. Sistem administrasi yang di buat oleh sekolah pada dasarnya adalah untuk meminimalisir terjadinya tindakan kecurangan. Artinya bahwa sistem yang baik jika tidak di awasi dengan baik maka aka percuma.

2. Terdapat pengaruh yang signifikan antara lingkungan kerja terhadap fraud secara parsial. Lingkungan kerja merupakan faktor yang mempengaruhi terhadap terjadinya perlaku fraud artinya bila lingkungan kerja tidak nyaman maka akan terjadi peningkatan terhadap potensi fraud.

3. Tidak terdapat pengaruh yang signifikan antara personal attitude terhadap fraud secara parsial. Sikap seseorang merupakan hal yang paling menentukan bai buruknya perilaku tersebut dengan di pengaruhi oleh lingkungan rumah, perhatian serta masyarakat dan sebagainya. Sikap yang menunjukan perilaku yang baik belum tentu seseorang tersebut tidak melakukan tindakan fraud. Jadi dalam pengawasan yang perlu ditingkatkan adalah saling memahami dan saling mengingatkan antara yang satu dengan yang lainnya.

4. Terdapat pengaruh yang kurang signifikan antara sistem administrasi terhadap fraud secara parsial. Bahwa sistem yang telah dibangunolehsekolahuntuksalingmengawasi tidak berpengaruh secara signifikan kepada para pegawai yang melaksanakan tugasnya. Tetapi bukan berarti sistem itu untuk di kurangi tetapi justru dengan sistem itu pengawas dapat melaksanakan evaluasi.

Dalam penelitian ini peneliti hanya mengambil objek yang terbatas. Jadi besar kemungkingan apabila sampel yang di ambil dengan populasi 
yang sangat besar akan mendapatkan hasil yang signifikan. Variabel yang digunakan oleh peneliti hanya mengambil tiga saja sedangkan beberapa variabel lain yang ada belum di teliti. Keterbatasan berikutnya yang peneliti temukan adalah tingkat pemahaman responden terhadap pertanyaan-pertanyaan yang ada di dalam kuesioner karena menyangkut tentang kepribadian seseorang dalam tindakan sehari-hari. Dari hasil penelitian yang telah dilakukan, ada beberapa saranyang dapat disampaikan antaralain, hasil penelitian ini diharapkan dapat memberikan kontribusi bagi para peneliti selanjutnya yang akan melakukan penelitian tentang tindakan fraud. Dan diharapkan dengan adanya tambahan referensi dari hasil penelitian ini dapat menambah teori baru khususnya dalam pencegahan terhadap tindakan fraud. Hasil penelitian ini bagi akademi adalah dengan adanya hasil ini dapat memberikan tambahan referensi dalam meneliti faktor-faktor yang mempengaruhi fraud serta dapat dijadikan tambahan sebagai bahan litelatur. Hasil penelitian ini dapat dijadikan untuk proses transformasi pengetahuan di dalam lingkunga ekolah. Bagi pihak sekolah hasil penelitian ini bagi sekolah adalah dapat digunakan untuk mengevaluasi setiap tindakan yang dilaksanakan oleh sekolah demi tercipatanya pendidikan yang baik serta dapat memberikan informasi kepada sekolah apa yang seharusnya dilakukan untuk terus dapat memperbaiki segala lini yang ada disekolah tersebut. Hasil penelitian ini semoga dapat memberikan pemahaman kepada masyarakat tentang pentingnya saling mengawasi antara pihak sekolah dengan masyarakat melalui komite sekolah tentang bahayanya perilaku fraud. Dan kegiatan yang dilakukan masyarakat akan mempengaruhi tindakan fraud tersebut.

\section{Daftar Pustaka}

Al Quran Dan Terjemahan (Mushaf Usmani)

Albrecht, W.S. (2003). Fraud examination. South Western: Thomson.

Association of Certified Fraud Examiner (ACFE). 2010. Report To The Nations On Occupational Fraud And Abuse.
Calista. (2014). Alternatif Untuk Bahaya Laten Korupsi. Retrieved Maret 2, 2014, http://myzone.okezone.com/content/ $\mathrm{read} / 2014 / 02 / 20 / 12385$

Fikri. (2012). Kejari: Kepala Sekolah SMAN 1 Tersangka Dugaan Korupsi BOS-BOM Rp. 500 Juta. Retrieved Februari 25, 2014, http:/ radarsukabumi.com

Fitrawansyah. (2014). Fraud dan Audit. Bogor: Mitra Wacana Media.

Hamdanah. (2012). Paradigma administrasi publik sebagai landasan teori administrasi pendidikan. Jurnal Falasifa.

Karyana, A. (2011). Ketidakpatutan dalam sistem administrasi Negara Kesatuan Republik Indonesia (SANKRI), perilaku fraud. Simposium Nasional Ilmu Administrasi Negara Untuk Indonesia di FISE Universitas Negeri Yogyakarta.

(2012). Kepsek-SMA-5 Sukabumi Didakwa Korupsi Rp. 519-Juta. Retrieved September, 29, 2014. http://www.inilahkoran.com /read/ detail/1879098/

Nashohah., Arofati, W., \& Aryani Tri. (2012, Desember). Prediktor intensi kecurangan akademik ditinjau dari minat personal, struktur tujuan kelas dan orientasi tujuan personal pada siswa SMA. Jurnal Psikologi Pendidikan dan Perkembangan.

Novitasari, A., Wahyudin, A., Setiyani, R. (2012). Pengaruh kepemimpinan kepala sekolah, lingungan kerja, pendidikan, dan pelatihan terhadap kinerja guru. Economic Education Analysis Journal.

Nur Ratr, K., Wahyu, M. (2012). Analisis faktor-faktor yang mempengaruhi terhadap kecenderungan kecurangan akuntansi dengan perilaku tidak etis sebagai variabel intervening. Diponegoro Journal of Accounting, Vol 1 No 1.

Nur Laily. Sukaris. 2011. Burnout Tenaga Pendidik Wanita Ditinjau Dari Lingkunga Kerja Psikologis Dan Dukungan Sosial. Seminar Nasional Ilmu Ekonomi Terapan, Fakultas Ekonomi UNIMUS

Ramdany. (2012). Analisis Faktor-faktor yang mempengaruhi fraud. Tesis, Pascasarjana 
Magister Akuntansi Universitas Pancasila.

Soedibjo., \& Bambang, S. (2005). Pengantar Metode Penelitian, Bandung: STIE-STMIK PASIM

Sofyan,. Dian , K. (2013). Pengaruh lingkungan kerja terhadap kinerja kerja pegawai BAPPEDA, MIEJ Journal.

Tuanakotta., \& Theodorus, M. (2010). Akuntansi Forensik dan Audit Investigatif, Edisi 2. Jakarta: Penerbit Salemba.

Undang-Undang Republik Indonesia Nomor 28 tentang Penyelengaraan Negara Yang Bersih Dan Bebas Korupsi, Kolusi Dan Nepotisme. 1999.

Undang-Undang Republik Indonesia Nomor 20 Tahun 2001 tentang Perubahan Atas UndangUndang Nomor 31 Tahun 1999 Tentang Pemberantasan Tindak Korupsi. 